larly of the Tachinids, it may be possible to encourage their increase by the selec tion of favorable crops, and a consideration of the most advantageous dates of seeding.

\title{
PSITHYRUS LABORIOSUS FABR. IN THE NESTS OF BUMBLEBEES
}

$$
\text { (HYM). }
$$

BY THEODORE, H. FRISON,

Urbana, Illinois.

Of the nine or possibly ten species of the genus Psithyrus occurring it America, North of Mexico, only two have ever been recorded from the nests of bumblebees. When Franklin's work on "The Bombidae of the New World" appeared in 1913, there had not been recorded a single authentic instance of a Psithyrus having been taken in a bumblebee's nest in this country. The fact that many American writers had mentioned the inquiline habits of Psithyrus was entirely due to the numerous European records on the subject.

Mr. F. W. L. Sladen in the Canadian Entomologist for March, 1915, was the first to record the finding of a species of Psithyru, in a Bremus (Bombus) nest in the Nearctic region. In this article he reports the discovery of Psithyrus insularis Sm. in the nest of Bremus (Bombus) flavifrons Cress. on July 7, 1914 at Agassiz, British Columbia. In April, 1916 in the Bulletin of the Brooklyn Entomological Society, the writer recorded the presence of Psithyrus variabilis Cress. in the nests of Bremus pennsylvanicus DeGeer in the summer of 1910 and 1915 at Champaign, Illinois. Several times since then, both in 1917 and 1920 , I have taken Psithyrus cariabilis Cress. in the nests of Bremus pennsylvanicus DeGeer.

On July 22, 1919 I removed to the laboratory for closer study a nest of Bremus (Bombus) pennsylvanicus Defeer. This nest was one of several started in domiciles I had buried in the ground for attracting searching bumblebee queens. The domicile was first noted as being inhabited on June 20, when ii contained a small honey-pot and eggs. As the queen was not in the nest I was unable to determine the species at this time (June 20). On July 22, when I removed the nest, it contained a queen and four small workers of Bremus pennsylvanicus DeGeer., besides five egg cells containing eggs, two brood masses, and fifteen pupal cocoons. In the nest material near the entrance were the remains of a queen of Bremus pennsylvanicus DeGeer and a queen of Psithyrus laboriosus Fabr. The two dead queens were mute testimony of the earlier history of this colony. Evidently after the nest was started another queen of Bremus pennsylaanicus DeGeer found it, and a struggle ensued over the possession of the nest. Such fighting over the nests is very common in late spring and early summer. Which queen finally won and stung the other to her death is an open question. The dead Psithyrus queen can only be accounted for in much the same manner, and all this goes to show that a Psithyrus queen is not always peaceably admitted into a bumblebee nest or victorious in a battle with the Bremus queen. The history of this colony was followed until September 16, and no Psithyrus were ever reared from the nest.

In a nest of Bremus (Bombias) auricomus Robt., about one and one-half 
feet below the surface of the ground, examined on July 26, at Clyman Junction, Wisconsin, I found a queen of Psithyrus laboriosus Fabr. In this instance also, the Psithyrus queen had evidently been stung by the queen bumblebee. When the Psithyrus queen was handled, it was barely able to move a leg, and acted in every respect like a bumblebee that had been stung. It was in the nest material near the entrance of the nest, probably having been dragged there by the Bremus queen. In the nest at the time, besides these two queens, were twelve workers, fifteen eggs, and some larvae and pupae. It was impossible to make a detailed study of the development of this colony in order to learn if any individuals of Psithyrus were eventually produced.

Whether any of the Nearctic species of Psithyrus are restricted to the nests of one particular species of Bremus or not is still to be decided. Sladen in the previously mentioned article, infers that Psithyrus insularis 'Sm. must at leasi frequent the nest of another species of bumblebee besides Bremus flavifrons Cress., as Psithyrus insularis Sm. occurs at Ottawa, Ontario where Bremus flave. frons Cress. is not indigenous. From the evidence given above, Psithyrus lab. ariosus Fabr. evidently invades the nests of both Bremus pennsylvanicus DeGeer and Bremus auricomus Robt., species representing the two subgenera of Bremus. If Psithyrus laboriosus Fabr. will enter the nests of two such widely separated species as these, it is reasonable to assume that it will frequent the nest of almost any species of bumblebee within its range. About Urbana, Tllinois, where Psithyrus cariabilis Cress. is very common, I have never found it in the nests of any bumblebee species but Bremus pennsylanicus DeGeer, and it remains for future investigation to decide whether Psithyrus variabilis Cress. has more than one host.

Edward Saunders in "The Hymenoptera of the British Islands" says that the species of Psithyrus appear not always to confine themselves to the same host. Hoffer, one of the closest students of the European Bremidae, reports finding P.sithyrus campestris Panz. in the nests of Bromus agrorum Fabr., $R$. silvarum Linn., and $B$. variabilis Schmied. Psithyrus rupestris Fabr. and $P$. vestalis Fouc., however, are apparently very closely associated with Brcmus lapidarius Linn. and B. terrestris Linn. Even these last two species of Psithyrus, as shown by Sladen in "The Humble-bee" occasionally lodge in a nest of another species of bumblebee.

\section{NOTES ON THE PREPARATORY STAGES OF GNOPHAELA VER. MICULATA G. AND R. BY F. C. WHITEHOUSE. \\ Red Deer, Alta.}

Mid-June 1919 I took some nearly full grown larvae of this species in a tamarack swamp near Red Deer, which pupated about a week later and emerged I1th to 14 th July. The larvae were feeding on the borage Mertensia virginica. [ wrote Dr. McDunnough inquiring if the life history were known, and received reply that the full grown larvae had been twice described in Entomologica Americana $1 \mathrm{~V}, 24$ and $\mathrm{V} .57$ but that he had no knowledge of any published notes on the egg or early larval stages. He was kind enough to send me copies of the descriptions referred to. 